\title{
Kadar Laktat Darah sebagai Prediktor Kontaminasi Bakteri pada Hernia Inguinalis Lateralis Strangulata
}

\author{
Anthony Pratama, Haryono Yarman, Bambang A. S. Sulthana \\ Departemen Ilmu Bedah Fakultas Kedokteran Universitas Padjadjaran \\ Rumah Sakit Dr. Hasan Sadikin Bandung
}

\begin{abstract}
Abstrak
Hernia inguinalis lateralis strangulata merupakan salah satu kasus akut abdomen yang harus segera ditangani. Hernia yang mengalami strangulasi akan mengalami kerusakan integritas sel dan barier mukosa usus sehingga terjadi kontaminasi bakteri. Selain itu, sel usus yang strangulasi akan mengalami metabolisme anaerob yang menyebabkan peningkatan kadar laktat darah. Oleh sebab itu dilakukan penelitian untuk menilai hubungan antara kadar laktat darah dan kontaminasi bakteri pada keadaan strangulasi hernia. Metode penelitian bersifat potong lintang, data prospektif, penderita dengan hernia inguinalis lateralis strangulata yang datang ke Rumah Sakit Dr. Hasan Sadikin Bandung periode Mei 2011-April 2012. Dilakukan pengukuran kadar laktat darah saat penderita datang dan cairan peritoneum yang berasal dari kantung hernia diambil saat operasi. Dilakukan analisis data dengan uji regresi logistik. Subjek penelitian berjumlah 30 orang, terdiri atas 28 lakilaki dan 2 perempuan. Usia rata-rata subjek penelitian 58,5 $\pm 12,86$ tahun. Nilai kadar laktat darah rata-rata $1,76 \pm 0,36 \mathrm{mmol} / \mathrm{L}$. Hasil kultur kuman cairan peritoneum terbanyak Escherichia coli. Terdapat hubungan sangat kuat dan sangat bermakna antara kadar laktat darah dan kejadian kontaminasi bakteri, nilai $\mathrm{r}=0,817$ dan $\mathrm{p}=0,007(\mathrm{p}<0,01)$. Simpulan, kadar laktat darah dapat dijadikan sebagai alat ukur untuk memperkirakan kontaminasi bakteri pada penderita hernia inguinalis lateralis strangulata. [MKB. 2013;45(1):44-9]
\end{abstract}

Kata kunci: Hernia inguinalis lateralis strangulata, kadar laktat darah, kontaminasi bakteri

\section{Blood Lactate Levelas Predictor of Bacterial Contamination in Strangulated Groin Hernia}

\begin{abstract}
Strangulated groin hernia is one of the acute abdomen and have to be treated immediately. Strangulated hernia will cause damage of cell integrity and barrier of intestinal mucous, which make bacterial contamination occur. Strangulated intestinal cells will have anaerobic metabolism which make the blood lactate level increased. Therefore study was conducted to know the correlation between blood lactate level and bacterial contamination in strangulated groin hernia. The study method was cross-sectional with prospective data, patients with strangulated groin hernia who came to Dr. Hasan Sadikin Hospital Bandung during May 2011-April 2012. Blood lactate level was measured when the patient came to hospital and the peritoneal fluid which came from the hernial sac was taken intraoperatively. The data were analyzed with regression logistic test. There were 30 subjects in this study, 28 males and 2 females. The average age was $58.5 \pm 12.86$ years old. The average blood lactate level was $1.76 \pm 0.36 \mathrm{mmol} / \mathrm{L}$. The most found bacterial culture was Escherichia coli. There was strong and very significance correlation between blood lactate level and bacterial contamination, $r=0.817$ and $p=0.007(p<0.01)$. In conclusion, blood lactate level can be a predictor for bacterial contamination occurrence in patient with strangulated groin hernia. [MKB. 2013;45(1):44-9]
\end{abstract}

Key words: Bacterial contamination, blood lactate level, strangulated groin hernia

Korespondensi: Anthony Pratama, dr., M.Kes, AIFO, Departemen Ilmu Bedah Fakultas Kedokteran Universitas Padjadjaran -RS Dr. Hasan Sadikin Bandung jalan Pasteur No. 38 Bandung, mobile 081931368388, e-mail anthonypratama@yahoo.com 


\section{Pendahuluan}

Hernia inguinalis lateralis merupakan kasus yang banyak ditemui dan sekitar 800.000 penderita menjalani operasi herniorafi setiap tahunnya. Sebanyak 90\% kasus hernia terjadi pada lakilaki dan $10 \%$ pada perempuan. ${ }^{1}$ Insidensi hernia inguinalis lateralis yang mengalami inkarserasi atau strangulasi bervariasi $5-15 \%$ pada seluruh dunia. Berdasarkan data dari rekam medis Rumah Sakit Dr. Hasan Sadikin Bandung (RSHS) tahun 2008 sampai 2010 terdapatnya 294 kasus hernia inguinalis lateralis yang mengalami inkarserata dan strangulata, 284 kasus terjadi pada laki-laki dan 10 kasus pada perempuan. ${ }^{2}$ Hernia inguinalis lateralis inkarserata dan strangulata merupakan kasus akut abdomen yang harus segera ditangani oleh karena dapat memengaruhi morbiditas (19$30 \%$ dan juga mortalitas $(1,4-13,4 \%) .^{3}$ Pada keadaan inkarserasi dan strangulasi telah terjadi translokasi bakteri yang dapat menjadi sumber infeksi serta mengganggu proses penyembuhan luka. Percobaan pada binatang coba membuktikan translokasi bakteri akibat gangguan fungsi barier mukosa usus pada obstruksi total usus. Translokasi bakteri terjadi dalam 6-12 jam setelah obstruksi usus. Gangguan pada barier ini akan terjadi sejak awal obstruksi, disusul dengan dilatasi retikulum endoplasma, edema mitokondria, dan akhirnya terjadi nekrosis sel epitel (apoptosis) dalam 6-12 jam setelah obstruksi. Akibat penurunan perfusi dinding usus tersebut menyebabkan kerusakan barier mukosa. Setelah integritas mekanik usus hilang, maka bakteri dapat menginvasi submukosa serta memasuki sirkulasi sistemik melalui vena porta dan sistem limfatik. ${ }^{4-7}$ Beberapa substansi bakteri dapat ditemukan dari cairan peritoneum dan jaringan limfatik, bahkan bila tidak terjadi perforasi. ${ }^{4}$ Pada keadaan obstruksi dan strangulasi usus, kadar laktat darah merupakan salah satu indikator kimiawi darah yang dapat diukur. Pada keadaan obstruksi disertai strangulasi usus akan terjadi penurunan aliran darah yang menyebabkan iskemia dan penurunan perfusi jaringan. Pada keadaan tersebut, oksigen sebagai sumber energi sistem metabolisme aerobik tidak dapat berperan, sehingga untuk sumber energi digunakan sistem metabolisme anaerobik dan laktat sebagai hasil produk akhir. Dengan demikian, kadar laktat bisa dipakai untuk menilai keadaan iskemia usus yang mengalami obstruksi dan strangulasi tersebut. ${ }^{8,9}$

Beberapa gejala dan tanda strangulasi yaitu nyeri perut terus menerus, panas, takikardia, dan leukositosis. ${ }^{4}$ Gejala tersebut memiliki sensitivitas $82 \%$ untuk menentukan strangulasi. ${ }^{4,10}$ Dinding usus yang nekrosis biasanya akan mengeluarkan enzim creatine phosphokinase (CPK), lactate dehydrogenase (LDH), serta glutamic pyruvic transaminase (GPT). Kadar laktat serum juga meningkat pada usus nekrosis. ${ }^{4,11-13}$ Penelitian pada kuda dengan terjadi volvulus, kadar laktat plasma secara signifikan lebih rendah pada kuda yang selamat $(2,98 \pm 2,53 \mathrm{mmol} / \mathrm{L})$ dibandingkan dengan yang tidak bertahan hidup $(9,48 \pm 2,53$ $\mathrm{mmol} / \mathrm{L}$ ) dan pada usus yang viabel kadar laktat lebih rendah $(3,30 \pm 2,85 \mathrm{mmol} / \mathrm{L})$ dibandingkan dengan yang tidak viabel $(9,1 \pm 6,09 \mathrm{mmol} / \mathrm{L})$. Konsentrasi laktat plasma $<6 \mathrm{mmol} / \mathrm{L}$ memiliki sensitivitas sebesar $84 \%$ serta spesifisitas $83 \%$ untuk memprediksi angka harapan hidup kuda. ${ }^{9}$ Penelitian Alvarez dkk. ${ }^{14}$ menunjukkan kenaikan laktat pada $86 \%$ usus yang mengalami gangren. Lama obstruksi juga memengaruhi strangulasi, oleh Derrici dkk. ${ }^{3}$ diambil sebagai patokan $<8$ jam belum terjadi strangulasi atau $>8$ jam telah terjadi strangulasi. Berdasarkan data tersebut maka kadar laktat darah dapat dijadikan indikator strangulasi dan sejalan dengan kejadian kontaminasi bakteri dalam cairan peritoneum.

Penelitian pada 40 penderita dengan hernia inguinalis lateralis inkarserata tidak ditemukan kontaminasi bakteri patogen di dalam cairan peritoneum yang dilakukan di RSHS tahun 2011. Berdasarkan hasil penelitian tersebut, mesh dapat digunakan untuk operasi hernia inguinalis lateralis inkarserata. ${ }^{5}$ Pada operasi hernia strangulata yang belum terjadi perforasi penggunaan mesh masih kontroversi karena dikhawatirkan terjadi infeksi lokal akibat kontaminasi oleh bakteri. ${ }^{15-18}$ Kadar laktat darah dapat dipakai untuk mengetahui ada tidaknya kontaminasi oleh bakteri, sehingga kadar laktat darah dapat dijadikan patokan penggunaan mesh pada operasi herniorafi penderita hernia strangulata. Belum terdapat penelitian, khususnya di RSHS yang menilai hubungan antara kadar laktat darah dan kontaminasi bakteri dalam cairan peritoneum penderita hernia inguinalis lateralis strangulata yang belum terjadi perforasi. Oleh karena itu, penulis tertarik melakukan penelitian ini untuk menilai hubungan tersebut.

\section{Metode}

Subjek penelitian adalah penderita dengan hernia inguinalis lateralis strangulata yang datang ke Instalasi Gawat Darurat (IGD) Bedah RS Dr. Hasan Sadikin (RSHS) Bandung periode Mei 2011-April 2012 yang memenuhi kriteria inklusi dan eksklusi penelitian. Kriteria inklusi yaitu penderita hernia inguinalis lateralis strangulata yang menjalani operasi darurat dengan usia $>14 \square-$ 75 tahun, serta lamanya waktu strangulasi telah terjadi $\geq 8$ jam. Kriteria eksklusi yaitu penderita dengan penyakit jantung, diabetes melitus, sirosis hepatik, gagal ginjal kronik, penyakit keganasan, 
Tabel 1 Hubungan antara Kadar Laktat Darah dan Kontaminasi Bakteri Cairan Peritoneum pada Penderita Hernia Inguinalis Lateralis Strangulata

\begin{tabular}{llcccc}
\hline Variabel Dependen & Variabel Independen & Koefisien $\boldsymbol{\beta}$ & SE & $\begin{array}{c}\text { Nagelkerke } \boldsymbol{R} \\
\text { Square }\end{array}$ & $\mathbf{p}$ \\
\hline Kontaminasi bakteri & Kadar laktat darah & 10,175 & 3,765 & 0,817 & 0,007 \\
& Konstanta & $-18,007$ & 6,385 & & 0,005 \\
\hline
\end{tabular}

Keterangan: nilai $p$ bermakna jika hasilnya $p<0,05$

dan autoimun. Kriteria drop out jika pada saat intraoperasi ditemukan perforasi intestinal. Besar sampel menggunakan rule of thumbs sebanyak 30 sampel.

Penelitian potong lintang ini dilakukan secara prospektif, variabel bebas yaitu kadar laktat darah dan variabel terikat adalah kultur kuman cairan peritoneum penderita hernia inguinalis lateralis strangulata.

Semua penderita hernia inguinalis lateralis strangulata yang datang ke IGD Bedah RSHS dan memenuhi kriteria inklusi dan eksklusi penelitian serta menyetujui untuk ikut serta dalam penelitian (informed consent) dimasukkan sebagai subjek penelitian. Kadar laktat darah penderita diperiksa saat pertama kali datang dan belum mendapatkan tindakan atau pengobatan apapun. Pada persiapan perioperatif dilakukan resusitasi cairan. Pada saat dilakukan operasi, cairan peritoneum diambil saat pertama kali kantung hernia dibuka, lalu cairan yang diambil langsung dibawa ke laboratorium Patologi Klinik RSHS Bandung untuk dilakukan pemeriksaan kultur kuman dengan system Bact Alert ${ }^{\circledR}$ 120/BACTEC (Biomerieux).

Untuk menentukan hubungan antara variabel bebas dan terikat digunakan uji stastistik regresi logistik. Analisis regresi logistik menggunakan program SPSS for windows versi 16 pada derajat kepercayaan $95 \%$ dengan nilai $\mathrm{p} \leq 0,05$.

\section{Hasil}

Karakteristik subjek penelitian meliputi usia dan jenis kelamin. Usia rata-rata $58,5 \pm 12,86$ tahun dan 28 orang laki-laki. Kadar laktat darah ratarata $1,76 \pm 0,36 \mathrm{mmol} / \mathrm{L}$. Nilai median kadar laktat darah 1,6 mmol/L (Gambar1). Pada 13 penderita ditemukan bakteri dalam cairan peritoneumnya, sedangkan sisanya 17 penderita tidak ditemukan bakteri. Jenis kuman yang paling banyak adalah Escherichia coli (Gambar 2).

Uji statistik regresi logistik digunakan untuk menilai hubungan antara kadar laktat darah dan kontaminasi bakteri cairan peritoneum, dengan derajat kepercayaan $95 \%$ dan nilai $\mathrm{p}<0,05$. Uji ini dapat digunakan karena uji kococokan data dengan menggunakan Uji Hosmer dan Lemeshow menunjukkan hasil chi-kuadrat 9,155; $\mathrm{p}=0,165$ ( $\mathrm{p}$ dianggap valid jika $\mathrm{p}>0,05$ ).

Berdasarkan penghitungan statistik dengan mempergunakan uji regresi logistik menunjukkan hasil terdapat hubungan yang sangat kuat antara kadar laktat darah dan kontaminasi bakteri cairan peritoneum penderita hernia ingunalis lateralis strangulata dengan nilai $r=0,817$ serta $p=0,007$ (Tabel 1).

Selanjutnya ditentukan titik potong (cut-off point) kadar laktat darah terhadap kontaminasi bakteri cairan peritoneum dengan menggunakan kurva receiver operating characteristic (ROC). Berdasarkan kurva ROC didapatkan hasil nilai titik potong (cut-off point) kadar laktat adalah 2,1 $\mathrm{mmol} / \mathrm{L}$ (Gambar 3), lalu dibuat tabel proporsi $2 \times 2$. Kadar laktat darah terhadap ada tidaknya kontaminasi bakteri memiliki sensitivitas $77 \%$, spesifisitas $100 \%$, nilai duga positif $100 \%$, nilai duga negatif $85 \%$, dan akurasi $90 \%$ pada nilai titik potong $2,1 \mathrm{mmol} / \mathrm{L}$ (Tabel 2 ).

Tabel 2 Nilai Titik Potong Kadar Laktat Darah terhadap Kontaminasi Bakteri Cairan Peritoneum berdasarkan Receiver Operating Characteristic (ROC)

\begin{tabular}{cccc}
\hline & \multicolumn{2}{c}{ Kombinasi Bakteri Cairan Peritoneum } & \\
\cline { 2 - 3 } Kadar Laktat $(\mathbf{m m o l} / \mathbf{L})$ & Ada & Tidak Ada & Total \\
\hline$\geq 2,1$ & 10 & 0 & 10 \\
$<2,1$ & 3 & 17 & 20 \\
Total & 13 & 17 & 30 \\
\hline
\end{tabular}




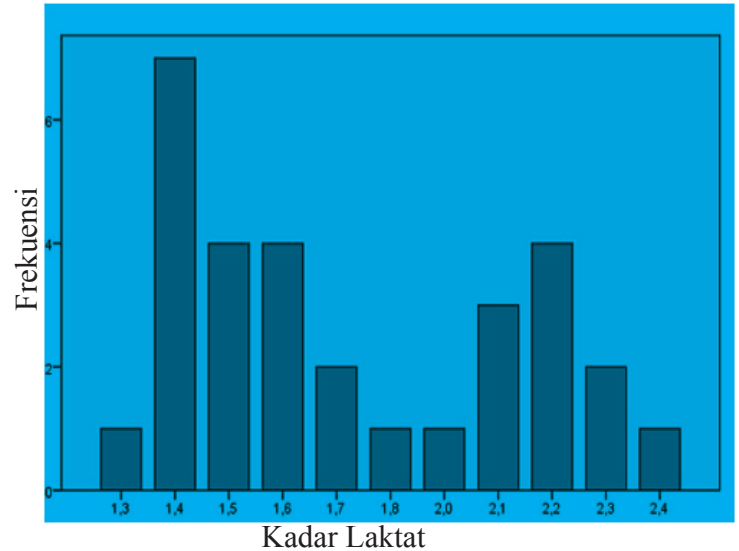

Gambar 1 Kadar Laktat Darah $(n=30)$

\section{Pembahasan}

Berdasarkan hasil statistik menunjukkan terdapat hubungan yang sangat bermakna antara kadar laktat darah dan kontaminasi bakteri dalam cairan peritoneum, nilai $\mathrm{r}=0,817 ; \mathrm{p}=0,007$ (uji regresi logistik, $\mathrm{p}<0,01)$. Keadaan tersebut menandakan bahwa semakin tinggi kadar laktat darah maka akan semakin besar kemungkinan kontaminasi bakteri dalam cairan peritoneum penderita hernia inguinalis lateralis strangulata. Selain itu, pada penelitian ini didapatkan pula nilai titik potong kadar laktat darah untuk menentukan ada tidaknya kontaminasi bakteri dalam cairan peritoneum yaitu sebesar $2,1 \mathrm{mmol} / \mathrm{L}$. Bila pada pemeriksaan ditemukan kadar laktat darah $<2,1 \mathrm{mmol} / \mathrm{L}$ maka kemungkinan besar tidak terjadi kontaminasi

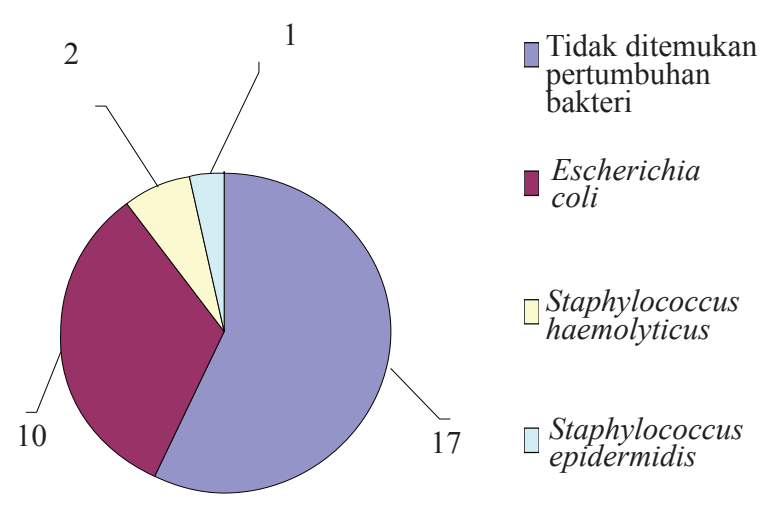

Gambar $2 \underset{(\mathbf{n}=30)}{\text { Hasil Kultur Cairan Peritoneum }}$

bakteri dalam cairan peritoneum pada penderita hernia inguinalis lateralis strangulata. Sebaliknya, jika pada pemeriksaan kadar laktat $\geq 2,1 \mathrm{mmol} / \mathrm{L}$ maka kemungkinan besar ditemukan kontaminasi bakteri dalam cairan peritoneum penderita hernia inguinalis lateralis strangulata.

Hasil ini sejalan dengan teori yang ada yaitu proses strangulasi akan menunjukkan kadar laktat darah serta menyebabkan integritas sel mukosa usus halus yang menyebabkan translokasi kuman.

Kadar laktat darah dapat digunakan sebagai alat ukur untuk menduga terjadinya kontaminasi bakteri dalam cairan peritoneum penderita hernia inguinalis lateralis strangulata. Kadar laktat darah memiliki akurasi dengan validitas prediktif yang cukup tinggi yaitu $90 \%$, karena mempunyai nilai duga positif dan negatif yang hampir mendekati

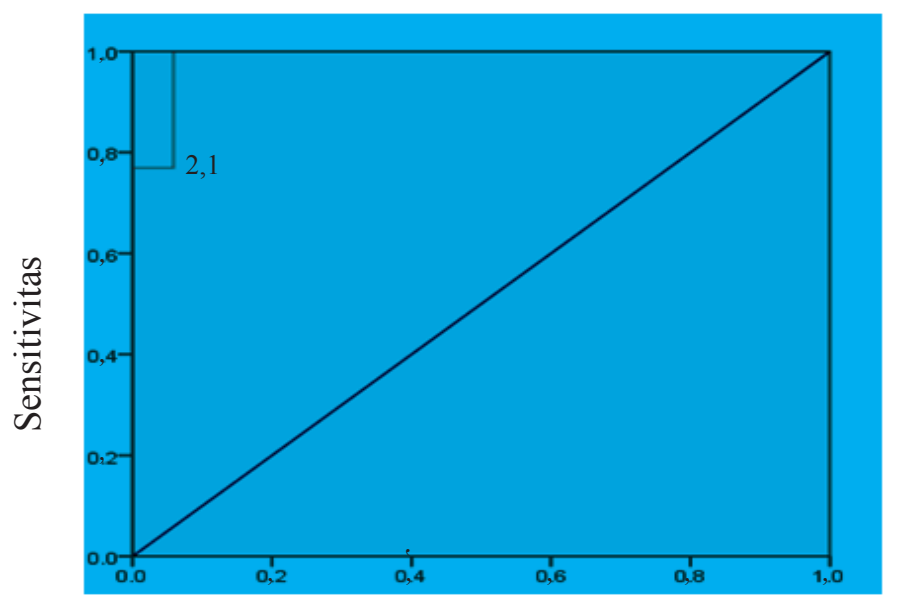

1- Spesifisitas

Gambar 3 Kurva ROC Pengukuran Kadar Laktat terhadap Kontaminasi Bakteri Cairan Peritoneum 
$100 \%$.

Pada penelitian ini terdapat tiga orang subjek penelitian yang mendapatkan hasil negatif palsu. Walaupun kadar laktat di bawah nilai prediksi 2,1 $\mathrm{mmol} / \mathrm{L}$, tetapi tetap saja ditemukan kontaminasi bakteri di dalam cairan peritoneum kantung hernia inguinalis lateralis strangulata. Berdasarkan teori seharusnya pada keadaan seperti itu sudah terjadi kontaminasi bakteri di dalam cairan peritoneum, tetapi berdasarkan penghitungan statistik belum terjadi. Hal tersebut dapat terjadi kemungkinan akibat panjangnya segmen usus yang mengalami strangulasi sehingga menyebabkan negatif palsu.

Aplikasi klinis penelitian ini yaitu apabila kadar laktat darah $\geq 2,1 \mathrm{mmol} / \mathrm{L}$ maka tindakan herniorafi yang dilakukan jangan menggunakan mesh, karena diduga telah terjadi kontaminasi bakteri yang dapat meningkatkan risiko infeksi. Penggunaan mesh sendiri menyebabkan proses inflamasi terjadi sehingga risiko terjadinya infeksi pada luka operasi akan meningkat. Sebaliknya, apabila kadar laktat darah $<2,1 \mathrm{mmol} / \mathrm{L}$ maka tindakan operasi herniorafi dapat digunakan mesh karena diduga tidak terjadi kontaminasi bakteri.

Terdapat hubungan yang sangat kuat antara kenaikan kadar laktat darah dan kontaminasi bakteri dalam cairan peritoneum penderita hernia inguinalis lateralis strangulata. Nilai titik potong kadar laktat darah yang dapat menduga terjadi kontaminasi bakteri di dalam cairan peritoneum penderita hernia inguinalis lateralis strangulata adalah 2,1 $\mathrm{mmol} / \mathrm{L}$. Nilai tersebut mempunyai sensitivitas sebesar $77 \%$ dan spesifisitas $100 \%$ serta akurasi alat ukur 90\% untuk mengukur kontaminasi bakteri di dalam cairan peritoneum penderita hernia inguinalis lateralis strangulata.

Simpulan, kadar laktat darah dapat digunakan sebagai salah satu alat ukur untuk menentukan kontaminasi bakteri di dalam cairan peritoneum penderita hernia inguinalis lateralis strangulata. Dengan prediksi tersebut, mesh dapat digunakan untuk operasi herniorafi penderita dengan hernia inguinalis lateralis strangulata, sehingga rekurensi hernia akan menurun.

\section{Daftar Pustaka}

1. Sherman V, Macho JR, Brunicardi FC. Inguinal hernias. Dalam: Brunicardi FC, Andersen DK, Billiar TR, Dunn DL, Hunter JG, Matthews JB, dkk, penyunting. Schwartz's principles of surgery. Edisi ke-9. New York: McGraw-Hill Companies, Inc; 2010. hlm. 1305-42.

2. Data Rekam Medis Rumah Sakit Dr. Hasan Sadikin Bandung 2008-2010.

3. Derici H, Unalp HR, Bodzag AD, Nazli O,
TansugT, KamerE. Factoraffecting morbidity and mortality in incarcerated abdominal wall hernias. Hernia. 2007;11(4):341-6.

4. Houghton SG, de la Medina AR, Sarr MG. Bowel obstruction. Dalam:Zinner MJ, Ashley SW, penyunting. Maingot's abdominal operation. Edisi ke-11. New York. McGrawHill Companies, Inc; 2007. hlm. 479-508.

5. Sidabutar UM. Hubungan antara lama obstruksi usus, warna dan kejernihan cairan peritoneum dengan kontaminasi bakteri pada penderita hernia inkarserata [tesis]. Bandung: Universitas Padjadjaran; 2011.

6. Papaziogas B, Lazaridis Ch, Makris J, Koutelidakis J, Patsas A, Grigoriou M, dkk. Tension-free repair versus modified Bassini technique (Andrews technique) for strangulated inguinal hernia: a comparative study. Hernia. 2005;9(2):156-9.

7. Wysocki A, Kulawik J, Pozniczek M, Strzalka M. Is the Lichtenstein operation of strangulated groin hernia a safe procedure? World J Surg. 2006;30(11):2065-70.

8. Debas HT. Gastrointestinal surgery. New York: Springer; 2004.

9. Johnston K, Holcombe SJ, Hauptman JG. Plasma lactate as a predictor of colonic viability and survival after 360 degrees volvulus of the ascending colon in horses. Vet Surg. 2007;36(6):563-7.

10. Mikkelsen ME, Miltiades AN, Gaieski DF, Goyal M, Fuchs BD, Shah CV, dkk. Serum lactate is associated with mortality in severe sepsis independent of organ failure and shock. Crit Care Med. 2009;37(5):1670-7.

11. Burt BM, Tavakkolozadeh A, Ferzoco SJ. Incisions, closures, and management of the abdominal wound. Dalam: Zinner MJ, Ashley SW, penyunting. Maingot's abdominal operation. Edisi ke-11. New York: The McGraw-Hill Companies, Inc; 2007. hlm. 71-102.

12. Beilman GJ, Dunn DL. Surgical infection. Dalam: Brunicardi FC, Andersen DK, Billiar TR, Dunn DL, Hunter JG, Matthews JB, dkk, penyunting. Schwartz's principles of surgery. Edisi ke-9. New York: The McGraw-Hill Companies, Inc; 2010. hlm. 113-33.

13. Kurt N, Oncel M, Ozkan Z, Bingul S. Risk and outcome of bowel resection in patients with incarcerated groin hernias: retrospective study. World J Surg. 2003;27(6):741-3.

14. Alvarez JA, Baldonedo RF, Bear IG, Solis JA, Alvarez P, Jorge JI. Incarcerated groin hernias in adults: presentation and outcome. Hernia. 2004; 8(2):121-6.

15. Tavakkolizadeh A, Whang EE, Ashley SW, Zinner MJ. Small intestine. Dalam: 
Brunicardi FC, Andersen DK, Billiar TR, Dunn DL, Hunter JG, Matthews JB, dkk., penyunting. Schwartz's principles of surgery. Edisi ke-9. New York: The McGraw-Hill Companies, Inc; 2010. hlm. 979-1012.

16. Aufenacker TJ, van Geldere D, van Mesdag T, Bossers AN, Dekker B, Scheijde E, dkk. The role of antibiotic prophylaxis in prevention of wound infection after Lichtenstein open mesh repair of primary inguinal hernia: a multicenter double-blind randomized controlled trial. Ann Surg. 2004;240(6):95560 .
17. Galeev YM, Lishmanov YB, Grigorev EG, Popov MV, Aparcin KA, Salato OV. Scintigraphic visualization of bacterial translocation in experimental strangulated intestinal obstruction. Eur J Nucl Med Mol Imaging. 2009;36(11):1822-8.

18. Kabaroudis A, Papaziogas B, Koutelidakis I, Kyparissi-Kanellaki M, Kouzi-Koliakou K, Papaziogas T. Disruption of the smallintestine mucosal barrier after intestinal occlusion: a study with light and electron microscopy. J Invest Surg. 2003;16(1):23-8. 